\title{
The Promises and Perils of Integrated Community Learning Environments
}

\author{
Stefan Welling \& Andreas Breiter \\ Institute for Information Management Bremen \\ welling@ifib.de\&abreiter@ifib.de
}

\begin{abstract}
Bridging the digital divide is a major endeavour in many cities, especially offering learning opportunities for underserved groups. As a major target group, teenagers are addressed. While the first stage was to provide access to technology, empirical research has shown that support is necessary to develop the necessary digital literacy. But as we will show, only full integration into the life world of teenagers will really support their learning process. Using examples from our fieldwork in a regional learning environment, we focus on schools and youth centres as being very important locations for the personal development teenagers. Through a careful analysis of strengths and weaknesses especially of the so-called Web.Punkte projects, we will suggest further activities to reach the next stage of life world integration.
\end{abstract}

\section{The Need for Improved Learning Environments}

Despite all variances, there is a common understanding among researchers, politicians and businesses that learning is a crucial condition for societal participation in its different shapes. This is especially true for living in the socalled information society where the ongoing diffusion of information and communication technologies (ICT) puts new demands and challenges on learning and learners. Additionally, ICT is becoming an integral component of the learning process itself (e.g. using instructional software to achieve certain learning goals). 
Since technological changes are continuous, an understanding and the capability for learning are needed to follow the developments.

Accordingly, many countries have started initiatives aimed at keeping up with the increasing impact of ICT on learning. But, as studies on the so-called 'digital divide' have shown, the effective and efficient use of digital media technologies and the necessary cultural capital for dealing with information and knowledge are unequally distributed. It seems that the less formal education one has the less likely it is that he or she will make use of digital media. Overall, especially socalled underprivileged groups have not been making the utilisation of the digital media part of their everyday life (Cooper 2000, Wilhelm et al. 2002, EOS Gallup Europe 2002). The lack of digital literacy, i.e. the competences needed for a meaningful utilisation of new media, correlates with general literacy deficits. Sufficient reading skills, for instance, are an indispensable pre-condition for Internet utilisation. It is striking that apparently many underserved youths do not meet these demands (OECD 2001). This can become a vicious circle because traditional cultural skills as literacy and numeracy are a prerequisite for using digital information and communication technologies effectively and efficiently for work, everyday activities and learning.

We argue that learning occurs in different ways and that the formal, mainly curriculum-based learning in school is only one facet of the learning environment that surrounds young people. Alternative learning opportunities, like in youth centres, can be more appropriate for those who fail in school and may also include ICT. Imagine, for instance, a group of young girls who often play tenant from school but meet regularly at a youth centre to practice hip-hop dancing. With the help of a youth worker, they take some pictures and together with some info text put it all together on a website to promote their activities. In this informal environment the girls gain new skills and self-confidence that may foster the achievement of additional biographical orientations.

In an integrated community learning network such activities may be the result of cooperation between schools and youth centres in a certain neighbourhood. Schools may open their computer labs in the afternoon for project-oriented media work with youth centres. Both institutions could use the same network infrastructure, bringing the idea of synergy into practice. Youth centre staff may call the same technical support service as schools and thereby profit from a joint user help desk as a single point of contact. Eventually, the cooperation takes off the ground when youth workers and teachers start to cut-off their biased opinions, attend joint-trainings and closely work together to serve the youths of their catchment area.

We will explore the possible benefits and challenges of an integrated community learning network for the improvement of learning in its different shapes especially for underserved youth. Building on the idea of the social proximate space as a major point of reference for the socialisation of children and 
youth we will first discuss the importance of cultural and social capital for learning. Underserved youth regularly only find limited opportunities to accumulate cultural and social capital. We argue that the conditions of learning and the acquisition of social and cultural capital could be improved significantly within a regional learning network. Public schools and the entities of youth work, which are, above all, youth centres, are two major players in such a network. Against the background of these two institutions we discuss the perils and the possible benefits of a community learning network. With regard to the age scope of the visitors or users of these institutions we focus on teenagers.

For this purpose we build on our experience from working with both entities for a considerable time in different contexts. With Web.Punkte (http://www.webpunkte-bremen.de) we ran a project that provided schools with an additional computer lab that should also serve the surrounding community. An extensive evaluation report provides valuable data for this paper (Breiter 2003a, 2003b). With PowerUP Bremen Neustadt we integrated a computer lab into a low-income neighbourhood and learned a lot about the challenges of computersupported youth work (Welling 2002). Extensive work on IT planning and management in schools, a research project about the conditions of a milieusensitive computer-supported youth work (Welling 2003) and the ongoing attempt to set up a regional learning network for the Bremen area provide us with further knowledge we build on for the purpose of this paper.

\section{Community Learning Cooperation for Underserved Youth}

Community learning can be conceptualised as any learning activity undertaken on an ongoing basis inside or outside educational institutions with the aim of improving individuals' literacy. The manifold notions of literacy, the confoundedness of the term with other variables as well as its covariance with other social factors as schooling, complicate the investigation of the term. Regularly, literacy is thought of as the ability to make "full sense and productive use of the opportunities of written language in the particular culture in which one lives" (Smith 1987: 143). Thereby, literacy is not "a neutral denoting of skills, it is always literacy for something - for professional competence in a technological world, for civic responsibility and the preservation of heritage, for personal growth and self-fulfilment, for social and political change" (Knoblauch 1990: 7576). From this understanding, literacy goes beyond a narrow cognitive skill but is rather a set of social practices. Its acquisition is therefore "a matter not only of cognition, or even of culture, but also of power and politics" (Warschauer 2003: 
45). Many of these practices are enacted within the so-called social proximate space (see figure 1).

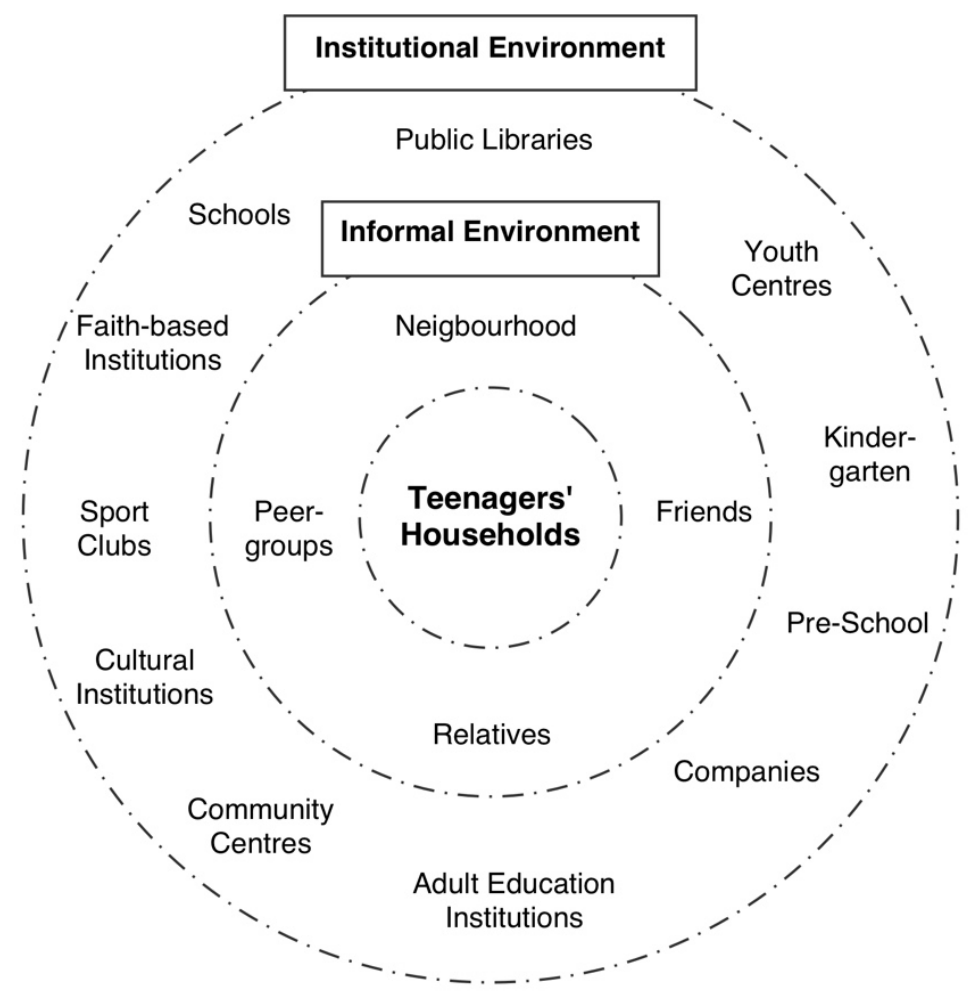

Figure 1: Learning environment within the social proximate space

The household is the core unit of the social proximate space. Most household's teenagers live in still consist of the traditional two-parent family even if the shapes of households have been becoming increasingly diverse. Different networks within the informal environment put teens in relation to relatives, friends and acquaintances and, what is especially important to peer-group members. Due to the timely expansion and intensification of the youth period, adolescents spend more and longer time in peer-groups than ever before. Apparently, youth has become it's own and most important reference group that shapes personality development and accomplishment of life (Ferchhoff 1999). For many youths, the peer-group is also the central location in the search for life orientations as a basis for the development of biographical perspectives (Bohnsack et al. 1995, Schäffer 1996, Nohl 2001). The informal environment is surrounded by several institutions, which also offer learning opportunities for individuals as well as for families. This institutional environment provides the basis for additional relations between staff members of these institutions and teenagers. 
The different relations and interdependencies within and between these two environments can also be thought of as a network. Such a network of more or less institutionalised settings of mutual awareness and acknowledgement, which embodies the entirety of current and potential resources, can also be referred to as social capital. These resources are based on the affiliation with groups like family, as well as relatives or groups mostly living in close proximity and they own shared norms, values and understandings (Putnam 2000: 18-25, OECD 2001). Within the household, social capital is especially important for the accumulation of cultural capital by the adolescent generation (Bourdieu 1986; Coleman 1988). Bourdieu differentiates between incorporated and institutionalised cultural capital. Whereas the first includes all kinds of knowledge somebody owns, the latter appears in the shape of advanced graduation certificates, apprenticeship certificates or academic certificates. The ability to acquire cultural capital is strongly influenced by the family of decent, so that this form of capital is heavily shaped by the circumstances of its first acquisition. Thus, the family provides the basic ground for the symbolic effectiveness of cultural capital.

Apparently, certain societal groups lack social capital to foster the development of cultural capital of their children. This is especially true for youth with migration background. In Germany, about forty percent (in 1998) of the native adolescents attended high school ('Gymnasium'), compared to only ten percent of the youths of non-German decent. More than two thirds of this group visited lower secondary schools (up to $9^{\mathrm{m}} / 10^{\text {th }}$ grade), compared to 20 percent of the German adolescents (Bundesregierung 2001: 122). Another indicator for a strong social exclusion from cultural capital of youth from non-German decent is the reading competence level. The recent study of the OECD Programme for International Student Assessment (PISA) among 15 years old revealed huge disparities. From almost half of the teenagers from migrant families who achieved not even reading competence level 1 more than 70 percent went through the complete German school system, which requires a compulsory education of at least nine to ten years (Baumert \& Schümer 2001: 379). Germany is the country with the highest correlation between social descent and educational success.

If we assume that digital media might support learning in and outside school, it is crucial to offer underserved youth opportunities to access and use these technologies. As empirical studies show, the intensity and quality of media use by these groups as well as the development of limited media practices may further increase this situation of disadvantage. On the other hand, digital media could provide new opportunities and chances for underserved youth. The most important precondition for such a strategy to be successful is the embedding of these technologies into the life world of the people. Yet, this has been achieved only in few projects. 


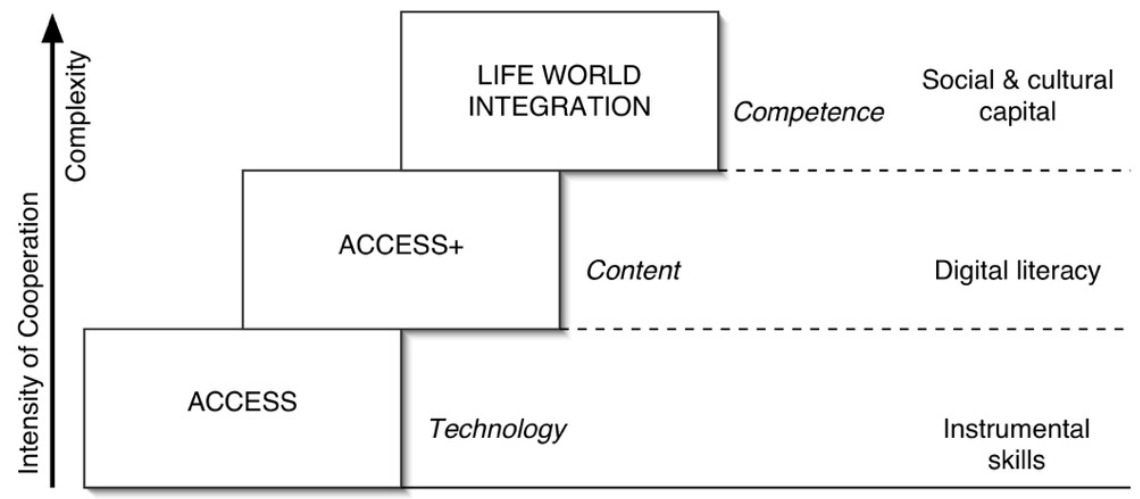

Figure 2: Stages of ICT integration for underserved youth

First attempts to provide opportunities to engage with new media for underserved groups were mainly focused on access to technology (stage 1). Early studies on the digital divide were mainly concerned about this unequal access. Accordingly, the first step was to equip educational institutions with computers and Internet connections where instrumental skills like keyboarding, word processing or basic Internet use could be learnt. Enormous amounts of money have been invested in hardware, software and networks. By the end of the decade, it became clear, that the digital divide is more than just an issue of equal access (NTIA 1999; NTIA 2000).

Stage 2 was to provide supported access (Access+) for specific user groups. This approach is mainly related to the necessary skills for effective use, about access to training and digital content (e.g. Servon 2002). This is the basic concept of digital literacy (Ba et al. 2003). But, as the work of Ba et al. illustrates, does the concept of "Access+" still do not include the user's perspective in a sufficient matter.

Following the definition of the American Library Association (ALA), the concept of digital divide has to be redefined as it characterizes differences in access to information through the Internet and other information and communication technologies and services, and in the knowledge, skills, and abilities to use information, due to geography, race, economical status, gender and physical ability (ALA 2002). Based on empirical evidence, we suggest a broader view on digital divide as well as necessary skills for underserved youth (stage 3). Hence, both human and social systems must also change and ICT must be integrated into the life world of teenagers.

"Access to ICT is embedded in a complex array of factors encompassing physical, digital, human and social resources and relationships. Content and language, literacy and education, and community and institutional structures 
must all be taken into account if meaningful access to new technology is to be provided.“ (Warschauer 2003: 6)

Given that, a stronger cooperation between the various institutions that surround the life world of teenagers is needed. While during the first two stages mainly bilateral agreements were necessary, especially between the 'parent organisations' of the learning institutions, the next step requires mutual understanding and support in a larger regional learning network (see figure 3 ).

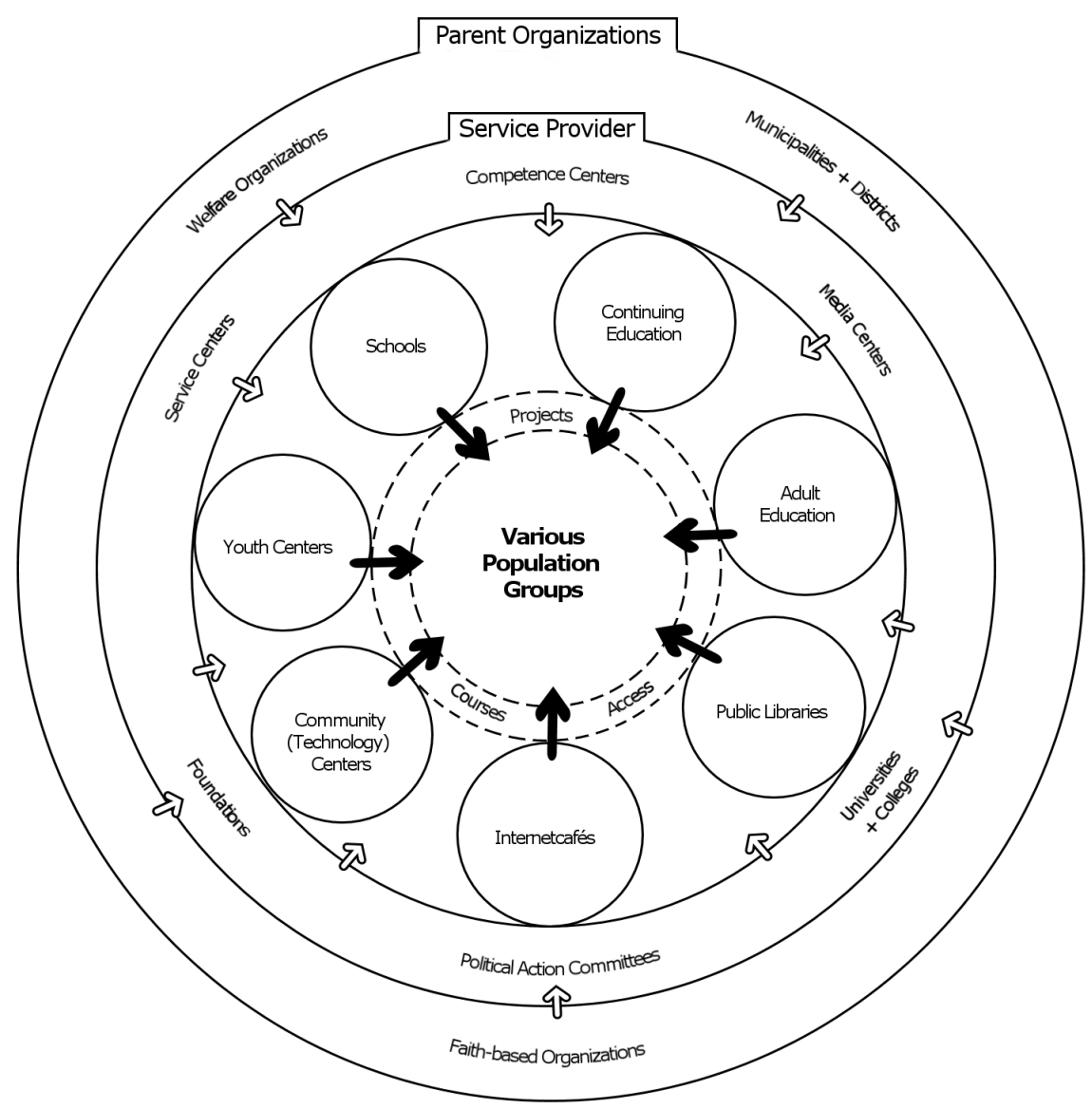

Figure 3: The Regional Learning Network

In order to sketch the complexity of cooperation and coordination, we will focus on two institutions that play the most important role for teenagers: schools and youth centres. Establishing cooperation between these two institutions is an ambitious venture. There is ongoing competition about resources, as both institutions are mainly financed by taxpayers' money but administered by different agencies. In Germany, faith-based institutions, charities and other notfor-profit organisation also sponsor youth centres but not schools. As schools are a constitutional task of the state, their financial support is more sustainable. For 
both institutions, the political action space is limited as they belong to hierarchical organisations but they report to different agencies which themselves tend not to cooperate. Due to their size, schools are key players within the community and play an important role for the majority of families with children. Youth centres are smaller, less visible and rather serve minority groups. Additionally, education of teachers and youth workers is different which results in different income and social status. Youth workers usually spent 3 years at a University of Applied Sciences ('Fachhochschule') and another year as apprentices. In most youth centres additional (often part time) staff does not necessarily hold a professional pedagocial degree. Turn over rate for these people are also often relatively high. This may effect the development of pedagogical strategies. Teachers have 4 years of university education, specialise in two or more subjects and gain practical experience during 2 years compulsory training in schools. During their education and even more during their work, they have developed different pedagogical philosophies and didactical approaches. Youth workers tend to favour informal learning in project-based environments with voluntary members while teachers work in institutionalised settings with compulsory members within a stronger curricular framework.

Regarding the pedagogical work with digital media, the gap is even larger. While teachers usually work in whole-class settings in computers labs - only few have PCs in their classrooms - using the computer as a tool, digital media are used flexibly and autonomously by participants in youth centres. The organisational environment and the individual action space are also different. From the schools' perspective, expanding school-community cooperation must be seen as an innovative process in connection with other reform efforts (such as accountability, autonomy, new curricula) that are loaded onto schools and their administrators. In most German state constitutions, opening the school for the community is a key goal and part of school development planning. From the youth centres' perspective, cooperating with schools requires a lot of effort to cross the boundaries between the pedagogical and professional visions.

\section{Web.Punkte in Bremen as Nodes of a Regional Learning Network}

In order to move one step beyond access to information and communication technologies, the State of Bremen (Germany) has set up a unique project as a public-private partnership with Deutsche Telekom AG. The idea was combining access to ICT with support (access + ). Schools build the core from which contentdriven activities with students as well as with members of the local community 
should take place in computer classrooms. As German schools are mainly parttime schools, other institutions such as youth centres, community centres or public libraries should also use the resources. The vision of the 'Web.Punkte' project was driven by five main goals:

1. Improving the schools' resources for access and use of digital media

2. broader use of IT resources in schools outside school hours

3. increasing community involvement

4. help to bridge the digital divide through providing the community with supported internet access

5. increasing student's competencies by intensive training to work as 'Web.Scouts' to support visitors

Schools had to go through an application process before they were accepted. The project application had to be approved first by the school board, which is the ultimate decision-making committee at the school level, consisting of principal, teachers, parents and students. The applications were ranked according to the following criteria: quality of the concept for community integration, regional distribution, plan for opening hours, selection and support of Web.Scouts (especially addressing gender issues and social background), and cooperation with parents' association. The implementation was divided into a 6 months pilot phase with six pre-selected schools. After that, the review committee received 30 applications (out of 60 eligible schools) and selected 19 sites with which a contract was negotiated. The schools received a refurbished and renovated room, a high value technical infrastructure (15 PCs, a laptop, peripherals, a fast T1-line for the Internet connection and a complete local area network) and the parents' association received funding to pay the Web.Scouts and for meeting ongoing costs.

During the formative evaluation with quantitative and qualitative methods (for details see Breiter 2003a), it became obvious, that school-community cooperation was only established in a few school sites and could only be achieved through an intensive coordination by the project management. Getting the local community involved was very ambitious and worked only in parts. The activities of the school to draw attention to use the Web.Punkt were very much dependent on the sites, the local project coordinator and the principal. Furthermore, schools with prior experience in working with the local community had an advantage although some new links could be established.

In many of the Web.Punkte, the initial external user group were senior citizens who took the opportunity to learn how to use the Internet with the help of the Web.Scouts. The effects of increased intergenerational communication between the different age groups are difficult to measure, but the reports, site visits and qualitative interviews showed impressive results. Hence, the group of Web.Scouts 
profited the most. Their motivation to come to school increased significantly and their teamwork with peers helped to support external users. Additionally, the students identified with their schools, regarding the Web.Punkt as their room, which they had to protect and to keep running. In most schools, the Web.Scouts were carefully selected according to gender and their social background. One school worked only with female Web.Scouts, another only with Web.Scouts with migrantion backgrounds. According to group interviews with Web.Scouts in selected locations, the students were very satisfied with the offered preparation courses that were especially designed for the project. The reward in the form of a certificate for participation was highly regarded.

Dual use of the equipment by youth centres, adult education centres and schools could only be achieved in a few sites. By far the majority of users ( 80 per cent) were students of the same school who used the equipment instead of their home PCs and valued the engagement with the peer group. Unexpectedly, most teenagers also had PCs at home, which implied that the Web.Punkt was a social room rather that a place to offer access to computer and Internet for "nonliners". During after-school hours most locations are dominated by students of the school and from other schools unless there were dedicated courses for teachers or other groups.

The problems of school-community integration and joint projects with youth centres can be analysed along the framework described above. There is a need of top-down initiatives in order to change culture and attitude - pressure of change. This is a necessary but not sufficient condition. At the same time bottom-up activities are crucial in order to keep on working. Wherever schools already had strong links to community centres and youth centres, the cooperation worked easily. Only in few examples, the envisioned move to life world integration has already been begun. One school works closely together with the youth centre, offering specific courses for single mothers with a migration background. The courses are taught employees of the youth centre. The female Web.Scouts (mostly themselves from migrant families) teach them how to use the Internet while volunteers looked after their younger children in the school. In another school, the initiative was started by a group of Turkish mothers who were interested in using the Web.Punkt for their specific training needs. With the help of a social worker, they offered courses for the neighbourhood, which were attracting other families.

The intensity of cooperation between the different agencies depends on the area and the problems to be solved. On the bottom end, cooperation to save scarce resources is much easier to establish than developing pedagogical content and working intensively with teenagers within their families and peer groups. From the perspective of the governing agencies for both schools and youth centres, due to limited public funding, the future lies in joint projects and a commonly used infrastructure. Economies of scale and increasing standardisation of hardware may foster the development of a common strategy. This includes central IT 
procurement processes and a shared network infrastructure (Internet access and value-added services) for all educational institutions. The cost of high bandwidth (which is becoming more and more important for high-quality digital material) is too high for youth centres. Attaching them to the schools' backbone will save resources and, additionally, allows to make joint Internet projects. Within the project Web.Punkte, the implementation of a user help desk was started. Currently, technical support for most schools is provided by a non-profit organisation, which has already been in charge of maintenance and service in schools for two years. Students from different faculties have helped schools with their technical problems. They have set up a user help desk with a call centre and a web-based FAQ-list. Additionally, they work on-site in schools. The support centre is working in more than 50 per cent of the schools in Bremen and might be extended to youth centres.

\section{Perspectives}

From our work in both youth centres and schools as well as in a project, which aimed to bring the two institutions together, we can derive the following results. There are small-scale impacts in some schools and some youth centres, which closely work together to support the development of their clients. Closer cooperation helps to build a better and mutual understanding about the basic orientations, attitudes, dispositions as well as interests and wants of teenagers as an important basis to serve their educational needs. The probably most important large-scale impact is the popularization of the idea to work with teenagers as Web.Scouts for peer-to-peer support. This approach is highly valuated among educators in both institutions as well as among students. It was already copied by other institutions which offer supported access and would like to move beyond thiss.

Our empirical research supports the fact, that digital divide is much more than a question of access to ICT infrastructure. There is a shared understanding among researchers that access to computers and Internet is a necessary but not a sufficient condition to allow all groups to participate in the so-called information society. Using digital media as tools to achieve individual goals require skills, which are unequally distributed. Hence, underserved youth need learning opportunities that go beyond digital literacy. Supporting underserved youth today is giving them the opportunity to participate in formal and informal learning activities as adults tomorrow. We can find today that more and more courses and learning content is delivered online. As most studies have shown, nonparticipation in education appears to be caused mainly by long-term socioeconomic background characteristics rather than access to ICT. There is yet no evidence that digital information and communication technologies are doing 
anything other than appealing to those who are already likely to be participants in formal learning processes.

School-community cooperation can help to fill the gap but needs investment in coordination. There is empirical evidence from the Web.Punkte that schoolcommunity cooperation can work if there is a long-term engagement from both sides and a common pedagogical understanding of the clients (teenagers). In order to establish such links, coordination is necessary which needs to combine actors from all institutions as well as from the administration. Going beyond the question of access, the next step is to produce, disseminate and share valuable digital material and pedagogical concepts. In special modules, key actors in both youth centres and schools could be trained in how to use digital media in formal and informal education processes. The courses might be created in a blended learning environment in order to combine methods of educating at a distance with digital media and traditional on-site education. Even more difficult is embedding digital media to support acquiring cultural capital into the life world of teenagers. This requires intensive cooperation and a common understanding between various social agencies and the readiness of families and teenagers to participate.

\section{References}

ALA (2002). Digital Divide. American Library Association. Office for Library Technology Policy. http://www.ala.org [14.03.2003]

Ba, H., Tally, W., \& Tsikalas, K. (2002). Investigating children's emerging digital literacies. In Journal of Technology, Learning, and Assessment, 1(4), http://www.jtla.org.

Baumert, J., \& G. Schümer (2001). Familiäre Lebensverhältnisse, Bildungsbeteiligung und Kompetenzerwerb. In Deutsches PISA-Konsortium (ed.): PISA 2000. Basiskompetenzen von Schülerinnen und Schülern im internationalen Vergleich (pp. 323-397). Opladen: Leske + Budrich.

Bohnsack, R., P. Loos, et al. (1995). Die Suche nach Gemeinsamkeit und die Gewalt in der Gruppe - Hooligans, Musikgruppen und andere Jugendcliquen. Opladen: Leske + Budrich.

Bourdieu, P. (1986). The Forms of Capital. In Richardson, J. G. (ed.): Handbook of Theory for the Sociology of Education (pp. 241-258) Westport, CON: Greenwood Press.

Breiter, A. (2003a). Public Internet Usage Points in Schools for the Local Community. Concept, Implementation and Evaluation of a Project in Bremen, Germany. Education and Information Technologies, 8(2), 109-125. 
Breiter, A. (2003b). Regional Learning Networks - Building Bridges Between Schools, University and Community. In T. van Weert \& B. Munro (eds.), Informatics and the Digital Society. Social, Ethical and Cognitive Issues (pp. 207-214). Boston, MA: Kluwer.

Bundesregierung (2001). Lebenslagen in Deutschland. Der erste Armuts- und Reichtumsbericht der Bundesregierung. Berlin, Bundesregierung.

Coleman, J. (1988). Social Capital in the Creation of Human Capital. In American Journal of Sociology (94), 95-120.

Cooper, M. (2000). Disconnected, Disadvantaged, and Disenfranchised: Explorations in the Digital Age. Consumer Federation of America, Consumer Union. http://www.consumerfed.org/digitaldivide/ disconnected102000.pdf [23.03.2001]

EOS Gallup Europe (2002). Flash Eurobarometer 125. . European Commission. Directorate General "Information Society", http://europa.eu.int/information society/eeurope/benchmarking/list/source_data_pdf/report_eb125_en.pdf [07.01.2003].

Ferchhoff, W. (1999). Aufwachsen heute: Veränderte Erziehungs- und Sozialisationsbedingungen in Familie, Schule, Beruf, Freizeit und Gleichaltrigengruppe. In Schell, F., Stolzenberg, E. and H. Theunert (eds.): Medienkompetenz. Grundlagen und pädagogisches Handeln (pp. 200-220). München, KoPäd.

Knoblauch, C. H. (1990). Literacy and the Politics of Education. In Lumsford, A.A., Moglen, H. and J. Slevinn (eds.): The Right to Literacy (pp. 74-78). New York: Modern Language Association.

Nohl, A.-M. (2001). Migration und Differenzerfahrung. Junge Einheimische und Migranten im rekonstruktiven Milieuvergleich. Opladen: Leske + Budrich

NTIA (1999). Falling Through the Net: Defining the Digital Divide. Washington, DC: National Telecommunications \& Information Administration. Washington, DC: U.S. Department of Commerce.

NTIA (2000). Falling Through the Net: Toward Digital Inclusion. Washington, DC: National Telecommunications \& Information Administration. Washington, DC: U.S. Department of Commerce.

OECD (2001). The Well--Being of Nations. The Role of Human and Social Capital. Centre for Educational Research and Innovation. Paris: OECD.

Putnam, R. D. (2000). Bowling Alone. The Collapse and Revival of American Community. New York: Simon \& Schuster.

Schäffer, B. (1996). Die Band - Stil und ästhetische Praxis im Jugendalter. Opladen: Leske + Budrich.

Servon, L. J. (2002). Bridging the Digital Divide: Technology, Community, and Public Policy. Malden, MA: Blackwell.

Smith, F. (1987). The Creative Achievement of Literacy. Awakening to Literacy. In Goellman, H Oberg, A.A. and F. Smith (eds.). The University of Victoria Symposium on Children's Response to a Literate Environment: Literacy Before Schooling (pp. 143-153). Exeter: Heinemann Educational Book. 
Warschauer, M. (2003). Technology and Social Inclusion: Rethinking the Digital Divide. Cambridge, MA: MIT Press.

Welling, S. (2002). PowerUP Bremen Neustadt and the Engagement of the Telecommunications Research Group in the Field of Computer-Supported Youth Work. http://www.fgtk.informatik.uni-bremen.de [10.01.2003].

Welling, S. (2003). Youth and New Media - Framing the Conditions of a MilieuSensitive Computer-Supported Youth Work. http://www.emtelconference.org [27.04.2003].

Wilhelm, T. et al. (2002). Connecting Kids to Technology: Challenges and Opportunities. http://www.aecf.org/publications/pdfs/snapshot_june2002.pdf [09.07.02]. 